\title{
Interpretation of a footing load test on a saprolitic soil from granite
}

\author{
A. VIANA DA FONSECA,${ }^{*}$ M. MATOS FERNANDES* and A. SILVA CARDOSO*
}

In the north-western region of Portugal residual soils from granite are dominant. Their porous cemented structure leads to a complex geotechnical behaviour, quite distinct from that of transported soils with a similar grain size distribution. The paper describes some of the studies carried out at an experimental site on which a fairly homogeneous saprolitic soil $6 \mathrm{~m}$ thick was encountered. These studies included: (i) a full-scale load test of a circular concrete footing $(1.20 \mathrm{~m}$ diameter), under carefully controlled conditions and with extensive monitoring; (ii) in situ testing techniques (SPT, CPT, SBPT, CH) and (iii) laboratory testing on highquality block samples, including triaxial tests with local strain measurement. The discussion is concentrated on the interpretation of the pressure-settlement curve from the footing load test, for a range of pressures typical of working conditions, by means of linear and non-linear elastic analyses based on stiffnesses from the laboratory and in situ tests. Some practical conclusions are extracted regarding the use of in situ and laboratory test results in analytical and empirical or semi-empirical methods for settlement estimation on these residual soils.

KEYWORDS: residual soils; deformation; footing; full-scale tests; in situ testing; laboratory tests.
Les sols résiduels du granit dominent le littoral de la région nord du Portugal. Les fabrique et structure de ces sols et particullièrement leur matrice cémentée et poreuse conduissent à des comportements géotechniques complexes, très différents des sols transportés avec granulométrie similaire. L'article décrit une partie des études réalisés sur un terrain expérimental où apparaissent des niveaux superficiels typiques des sols saprolitiques du granit de la région. Les études réalisés comprennent: (i) un essai de charge d'une semelle circulaire de béton armé (avec $1.20 \mathrm{~m}$ de diamètre), soigneuse et extensivement instrumentée; (ii) diverses essais in situ (SPT, CPT, SBPT, CH); (iii) essais en laboratoire sur des échantillons de haute qualité retirés des blocks taillés en puits, comprennant des essais triaxiaux avec instrumentation interne des déformations. La discussion est concentrée dans l'interprétation de la courbe de chargement-tassement obtenu de l'essai de charge de la semelle en utilisant des résultats des essais in situ et en laboratoire, considérant les niveaux de charge typiques des conditions de service. On extrait des conclusions sur l'application des résultats des essais in situ et en laboratoire aux méthodes empiriques et semi-empiriques pour l'évaluation des tassements des fondations en sols résiduels du granit.

\section{INTRODUCTION}

In the north-western region of Portugal residual soils from granite are dominant. The thickness of these regional saprolitic soils may sometimes attain $20 \mathrm{~m}$, with more common values of 5-10 m. Due to their specific genesis such soils present complex characteristics, which are a consequence, on the one hand, of their overall variability and inhomogeneity and, on the other hand, of the spatial arrangement and distribution of the particles and pore spaces. Coarse and resistant quartz grains are bonded by fragile clayey plagioclase bridges, resulting in a fabric with medium to high porosity. The feldspars are subjected to intense weathering

Manuscript received 15 October 1996; revised manuscript accepted 18 April 1996.

Discussion on this paper closes 1 November 1997.

* Faculdade de Engenharia da Universidade do Porto. processes, typical of high average annual precipitation and well-drained ground profiles. The mechanical and hydraulic behaviour of these soils is often quite distinct from that of transported soils with similar densities and grain size distributions.

Most of the current buildings and structures in the region are founded on footings on these soils. The behaviour of shallow foundations under typical working conditions, in which stress and strain levels induced in the ground are low to moderate, seems to be considerably dependent on the cemented structure of the saprolitic soil. This has been one of the main issues addressed in a research programme at the University of Porto on the geotechnical characterization and modelling of regional saprolitic soils.

A major part of the experimental work was carried out at a given site on which a fairly homogeneous saprolitic soil $6 \mathrm{~m}$ thick was encountered. The central element of the experiments was 
the execution of a load test on a $1.20 \mathrm{~m}$ diameter rigid reinforced concrete footing. In association with this test an extensive geological and geotechnical characterization was undertaken, including in situ testing [SPT, CPT, SBPT, cross-hole $(\mathrm{CH})$ ] and laboratory testing for chemical, mineralogical and physical identification, as well as oedometer and triaxial testing on high quality block samples.

In this paper the results of the experimental studies are presented and discussed, mainly in regard to the pre-failure deformation behaviour of the saprolitic soil. The pressure-settlement curve from the footing load test, for typical working load levels, is compared with those obtained by using simplified linear and non-linear elastic analyses based on deformation moduli taken from the laboratory and in situ tests.

\section{GENERAL CHARACTERIZATION OF THE EXPERIMENTAL SITE}

Figure 1 shows the experimental arrangement adopted for the footing test and the location of in situ tests in the vicinity.

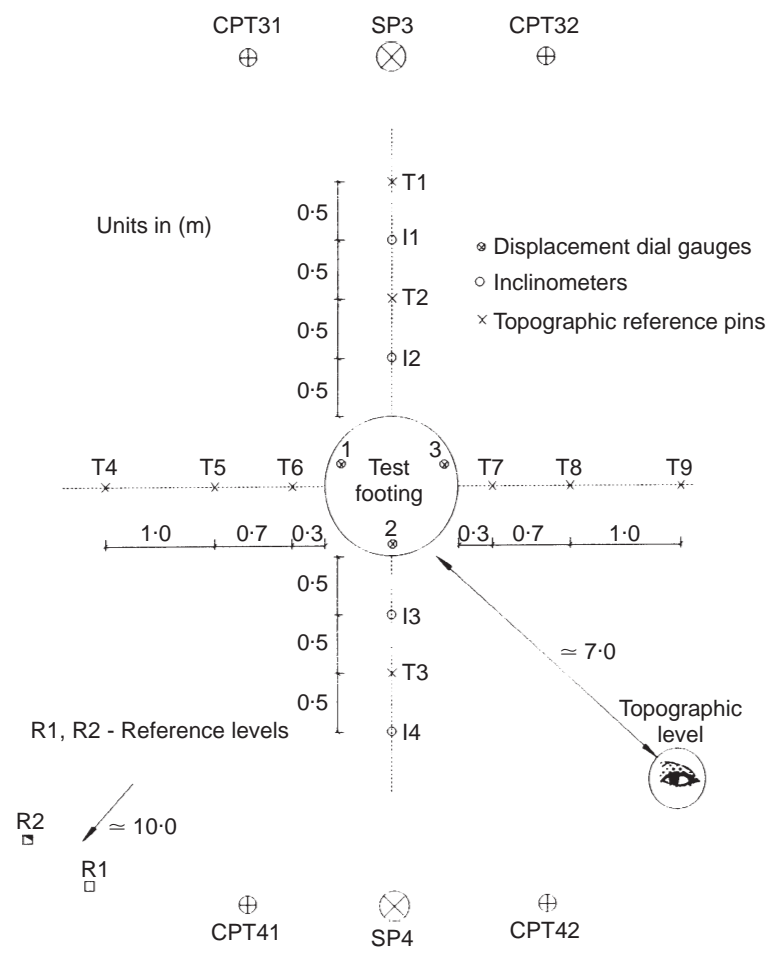

(a)

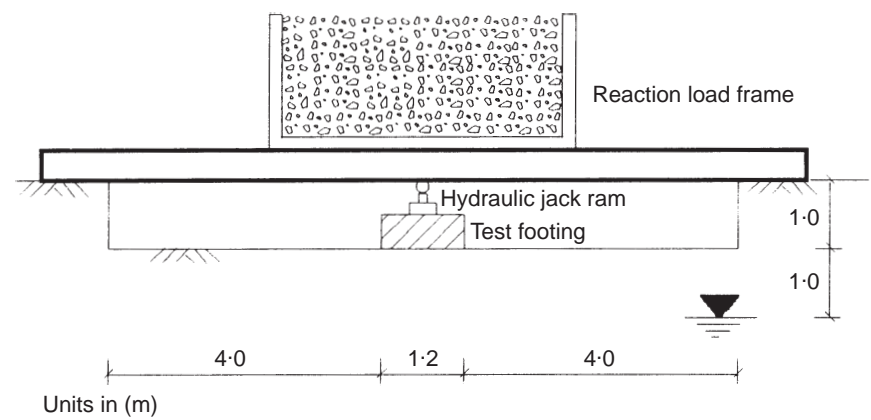

(b)

Fig. 1. Plan (a) and detailed cross-section (b) of the experimental site 
The results of SPT and CPT tests and the values of the maximum shear modulus, $G_{0}$, obtained from cross-hole tests are shown in Fig. 2. It is observed that the CPT cone resistance, $q_{c}$, increases linearly with the at-rest effective vertical stress, $\sigma^{\prime}$ vo whilst $G_{0}$ reveals a very low variation.

The variation of grain size distribution and Atterberg limits with depth is summarized in Table 1. This table contains the results obtained with specimens taken from the SPT sampler and from blocks trimmed in ditches 1-2 $\mathrm{m}$ deep. On the whole, the results reveal a fairly homogeneous ground profile which can be classified as SM (silty sand) or SM-SC (silty clayey sand) according to the Classification for Engineering Purposes (ASTM D2487, 1989).

Table 2 includes some natural physical properties of the soil at the experimental site and the corresponding typical range in the region (da Fonseca, Matos Fernandes, Cardoso \& Martins, 1994). The degree of saturation, $S_{\mathrm{r}}$, is very often in the range $90-95 \%$ and the corresponding suction levels are very low.

Table 3 presents some state indices commonly used for residual soils. In the Collins (1985) classification the values of $X_{\mathrm{d}}$ correspond to the metastable zone, which characterizes highly porous (flocculated) fabrics with an interparticle cemented matrix.

Figure 3 illustrates the plotting of the CPT test results on the Robertson (1990) classification chart. It can be observed that: (i) almost all values are situated in typical zones associated with cemented, aged or very stiff natural soils; (ii) with respect to grain size distribution the values fall mainly in the zones for sands or silt/sand mixtures.

\section{INITIAL STRESS STATE}

Regional experience suggests that values of the coefficient of earth pressure at rest, $K_{0}$, are relatively low. This is in agreement with the conclu-

Table 1. Grain size distribution and Atterberg limits

\begin{tabular}{|c|c|c|c|c|c|c|}
\hline & $\begin{array}{l}\text { Depth: } \\
\text { m }\end{array}$ & $\begin{array}{c}\text { Clay: } \\
\%\end{array}$ & $\begin{array}{l}\text { Silt: } \\
\%\end{array}$ & $\begin{array}{l}\text { Sand: } \\
\%\end{array}$ & $\begin{array}{c}\mathrm{w}_{\mathrm{L}}: \\
\%\end{array}$ & $\begin{array}{c}\mathrm{W}_{\mathrm{P}}: \\
\%\end{array}$ \\
\hline $\begin{array}{l}\text { Borehole } \\
\text { SP3 }\end{array}$ & $\begin{array}{l}1 \cdot 2 \\
1 \cdot 7 \\
2 \cdot 1 \\
2 \cdot 7 \\
3 \cdot 5 \\
4 \cdot 0 \\
4 \cdot 8 \\
5 \cdot 2 \\
5 \cdot 6 \\
6 \cdot 2\end{array}$ & $\begin{array}{l}8 \\
4 \\
6 \\
8 \\
3 \\
5 \\
5 \\
5 \\
5 \\
5\end{array}$ & $\begin{array}{l}25 \\
29 \\
26 \\
29 \\
23 \\
25 \\
29 \\
22 \\
21 \\
22\end{array}$ & $\begin{array}{l}62 \\
65 \\
63 \\
58 \\
68 \\
63 \\
59 \\
67 \\
67 \\
67\end{array}$ & $\begin{array}{l}28 \\
29 \\
27 \\
30 \\
31 \\
32\end{array}$ & $\begin{array}{l}25 \\
24 \\
19 \\
21 \\
28 \\
21\end{array}$ \\
\hline $\begin{array}{l}\text { Borehole } \\
\text { SP4 }\end{array}$ & $\begin{array}{l}0 \cdot 8 \\
1 \cdot 2 \\
1 \cdot 7 \\
2 \cdot 1 \\
2 \cdot 5 \\
3 \cdot 0 \\
3 \cdot 6 \\
4 \cdot 0 \\
4 \cdot 6 \\
5 \cdot 0 \\
5 \cdot 3 \\
6 \cdot 0\end{array}$ & $\begin{array}{l}7 \\
7 \\
6 \\
6 \\
6 \\
5 \\
5 \\
4 \\
5 \\
5 \\
4 \\
4\end{array}$ & $\begin{array}{l}19 \\
31 \\
24 \\
22 \\
24 \\
22 \\
20 \\
21 \\
21 \\
24 \\
22 \\
19\end{array}$ & $\begin{array}{l}64 \\
55 \\
65 \\
63 \\
59 \\
60 \\
64 \\
65 \\
64 \\
58 \\
62 \\
66\end{array}$ & $\begin{array}{l}32 \\
30 \\
28 \\
28 \\
28 \\
28 \\
31 \\
28\end{array}$ & $\begin{array}{l}25 \\
22 \\
24 \\
25 \\
22 \\
21 \\
\\
25 \\
26\end{array}$ \\
\hline Blocks & $1 \cdot 0-1 \cdot 5$ & $5-7$ & $14-23$ & $64-67$ & $28-40$ & $19-26$ \\
\hline
\end{tabular}

Table 2. Natural physical properties

\begin{tabular}{l|c|c|c|c|c}
\hline & $\gamma_{\mathrm{s}}: \mathrm{kN} / \mathrm{m}^{3}$ & $e$ & $S_{\mathrm{r}}: \%$ & $w: \%$ & $k: \mathrm{m} / \mathrm{s}$ \\
\hline Exp. site & $25 \cdot 7-26 \cdot 5$ & $0 \cdot 60-0 \cdot 85$ & $70-100$ & $15-27$ & $10^{-6}-10^{-5}$ \\
Regional & $25 \cdot 5-26 \cdot 7$ & $0 \cdot 40-0 \cdot 85$ & $60-100$ & $10-30$ & $10^{-6}-10^{-5}$ \\
\hline
\end{tabular}

$\gamma_{\mathrm{s}}$ : unit weight of solid particles; $e$ : void ratio; $S_{\mathrm{r}}$ : degree of saturation; $w$ : water content; $k$ : coefficient of permeability. 

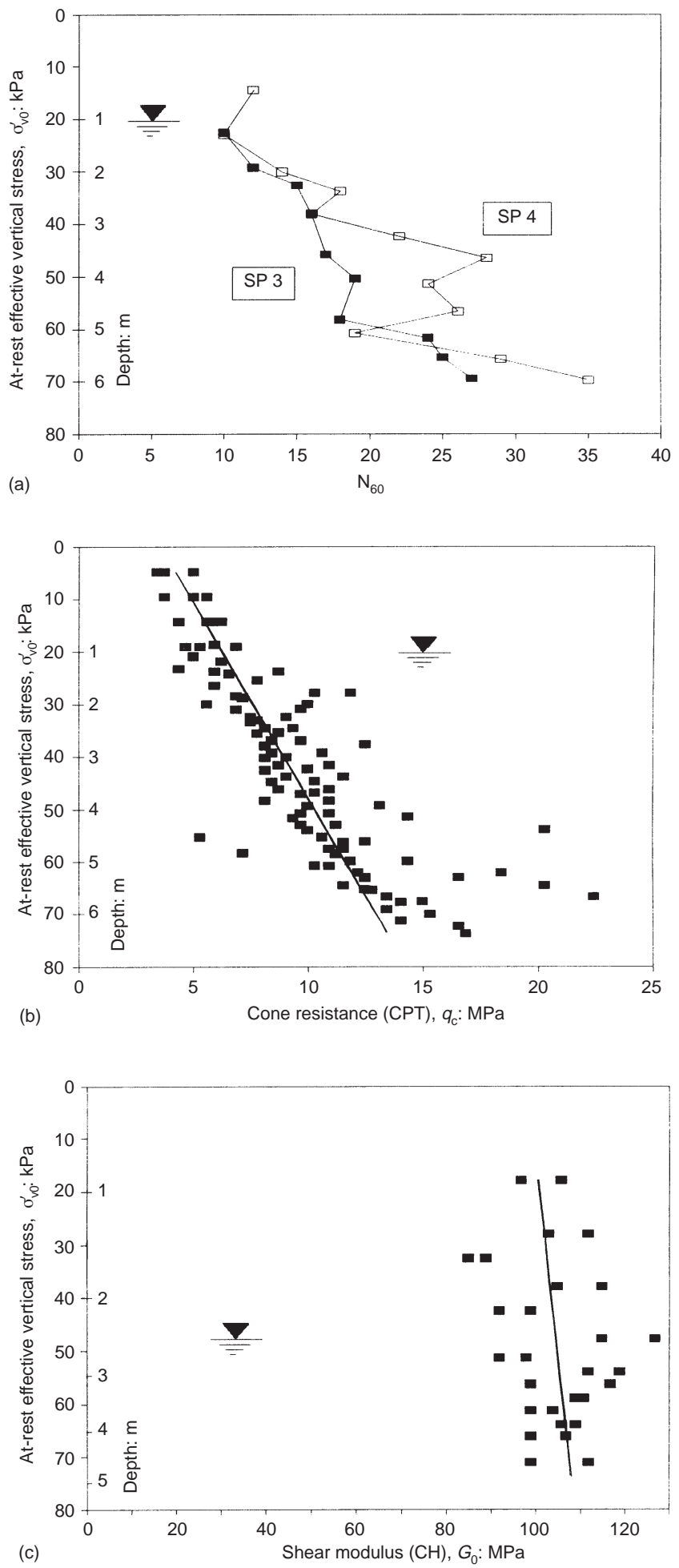

Fig. 2. In situ test results versus the at-rest effective vertical stress: (a) SPT; (b) CPT; (c) CH 
Table 3. Weathering and void ratio indices

\begin{tabular}{l|l|l}
\hline \multicolumn{1}{c|}{ Index (symbol) } & \multicolumn{1}{|c}{ Reference } & \multicolumn{1}{c}{ Values } \\
\hline Lixiviation index $(\beta)^{*}$ & Rocha Filho et al. $(1985)$ & $0 \cdot 40-0 \cdot 50$ \\
Degree of decomposition $\left(X_{\mathrm{d}}\right) \dagger$ & $\begin{array}{l}\text { Lumb (1962) } \\
\text { Collins (1985) }\end{array}$ & $0 \cdot 59-0 \cdot 63$ \\
Relative void ratio $\left(e_{\mathrm{r}}\right) \ddagger$ & Vaughan (1988) & $0 \cdot 72$
\end{tabular}

$* \beta=\mathrm{ba}_{1}$ (weathered rock) $/ \mathrm{ba}_{1}$ (sound rock), where $\mathrm{ba}_{1}=\left(\mathrm{K}_{2} \mathrm{O}+\mathrm{Na}_{2} \mathrm{O}\right.$ ) $/ \mathrm{Al}_{2} \mathrm{O}_{3}$.

$\dagger X_{\mathrm{d}}=\left(1-W_{\mathrm{f}} / W_{\mathrm{f} 0}\right) /\left(1+W_{\mathrm{f}} / W_{\mathrm{q}}\right)$, where $W_{\mathrm{q}}$ is the weight of quartz, unaltered by weathering, and $W_{\mathrm{f}}$ and $W_{\mathrm{f} 0}$ are the weight of feldspar in the soil and in the parent rock, respectively.

$\ddagger e_{\mathrm{r}}=\left(e-e_{\mathrm{opt}}\right) /\left(e_{\mathrm{L}}-e_{\mathrm{opt}}\right)$, where $e_{\mathrm{L}}$ and $e_{\mathrm{opt}}$ are the void ratio at the liquid limit and at the optimum dry density.

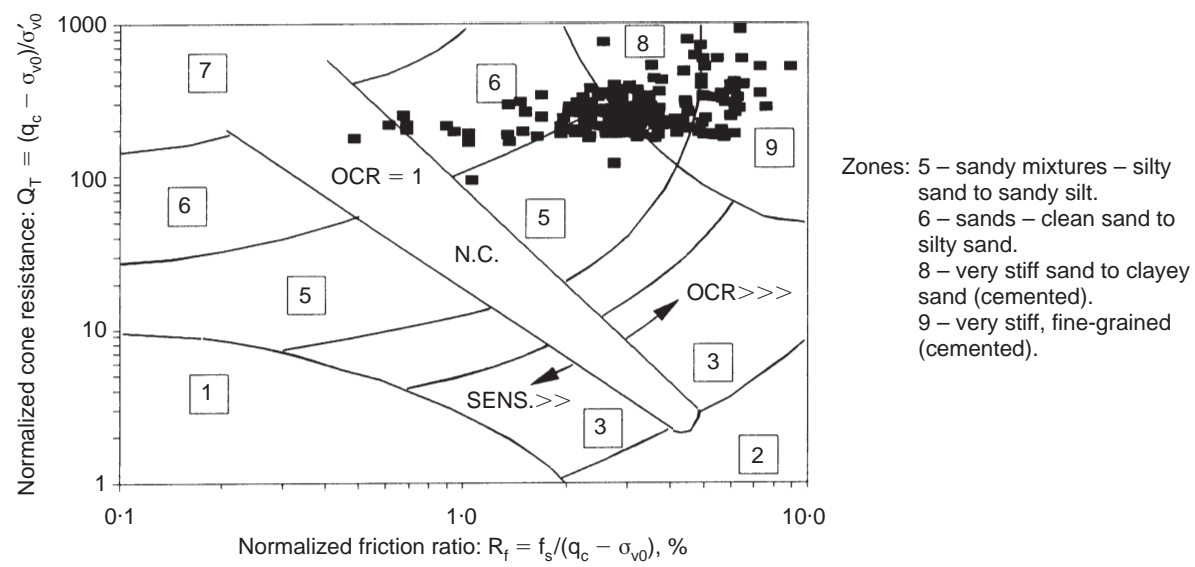

Fig. 3. Soil classification by the Robertson (1990) chart

sions of Vaughan \& Kwan (1984) for cases where the weathering processes do not generate expansible minerals.

The four tests with the Cambridge self-boring pressuremeter (SBPT) included in the experimental studies lead to an average value of $K_{0}$ equal to $0 \cdot 38$. This value has been globally corroborated by the results of incremental triaxial tests with null radial strain (da Fonseca, 1996).

\section{FOOTING LOAD TEST \\ General}

The instrumentation used for the footing load test consisted of (see Fig. 1): three displacement dial gauges with $50 \mathrm{~mm}$ travel and $0.01 \mathrm{~mm}$ divisions connected to the footing to record its settlement; nine reference pins to survey the deflection of the ground surface around the footing by means of topographic electronic equipment; and four vertical inclinometer tubes sealed at $6 \mathrm{~m}$ depth to measure horizontal displacements in the ground; the inclinometer tubes were also used to observe the position of the water table.

The loading process consisted of 35 load steps, including four unload-reload cycles. Values of the stabilization time fulfilled a criterion commonly considered as appropriate to saprolitic soils (GOST 20276, 1985 - national Soviet standard): the settlement shall not exceed $0.1 \mathrm{~mm}$ in a time interval of $4 \mathrm{~h}$. The whole duration of the test was approximately 15 days.

During the test the water level remained practically constant at $1 \mathrm{~m}$ depth.

Bearing in mind the number of loading stages, the piezometric readings and the adopted stabilization criterion, one can consider that the test was performed under drained conditions.

The loading process was concluded when the observed settlement reached around $10 \%$ of the footing diameter (ASTM D1194, 1989). The load at the last stage corresponded to a pressure of about $1000 \mathrm{kPa}$.

\section{Pressure-settlement curve}

The complete pressure-settlement curve from the footing load test is shown in Fig. 4(a). As can be seen in the enlargement of Fig. 4(b), there is a clear increase of the settlement rate with load for pressure values exceeding around $125 \mathrm{kPa}$. It should be noted that the time for settlement stabili- 

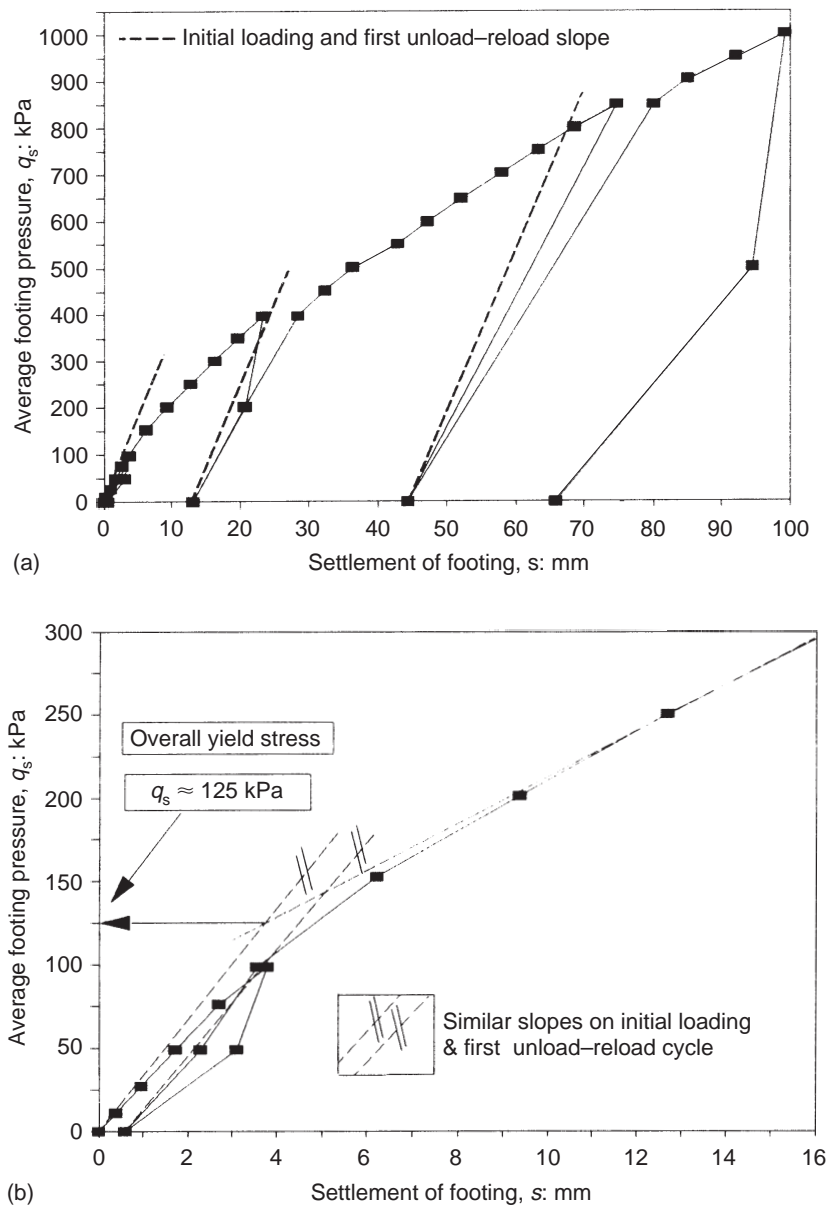

Fig. 4. Pressure-settlement curve of the footing load test: (a) general picture; (b) enlargement for $q_{\mathrm{s}} \leqslant 300 \mathrm{kPa}$

zation in each load step significantly increased above this pressure.

Although it is not precisely defined, this pressure seems to represent a transition from an essentially elastic behaviour to a phase in which the cemented structure of the soil is substantially damaged. This seems to be confirmed by the small difference between the inclination of the first loading curve and that of the first unload-reload cycle (Fig. 4(b)). In the subsequent cycles the unload-reload modulus is lower (Fig. 4(a)).

Figure 5 shows the vertical displacement of six of the reference pins on the ground surface around the footing. For the first load stages settlements increase at an approximately constant rate after which a stabilization occurs.

At the end of the test the rotation of the footing was measured with the help of a high precision clinometer. The measurements were performed on a smooth steel plate which had been previously fixed to the top of the footing and carefully levelled. The rotation angles were $1^{\circ} 20^{\prime}$, in the plane of the settlement points $\mathrm{T}_{4}$ and $\mathrm{T}_{9}$, and $30^{\prime}$, in the perpendicular plane. This rotation was also appreciated from the settlement measurements of the three dial gauges resting on the footing.

This rotation explains the fact that the settlements of points $T_{7}$ and $T_{8}$ become clearly smaller than the corresponding ones, $\mathrm{T}_{6}$ and $\mathrm{T}_{5}$ respectively, with the approach of the end of the loading process. Consistent differences of settlements between points $T_{4}$ and $T_{9}$ are not detected due to the large distance to the footing.

In relation to the horizontal displacements at the surface and in the ground in the vicinity of the footing, the recorded values are generally very small, most of them of the order of magnitude of the inclinometer equipment precision. The displacements observed at the two inclinometer tubes closest to the footing are illustrated in Fig. 6 for 

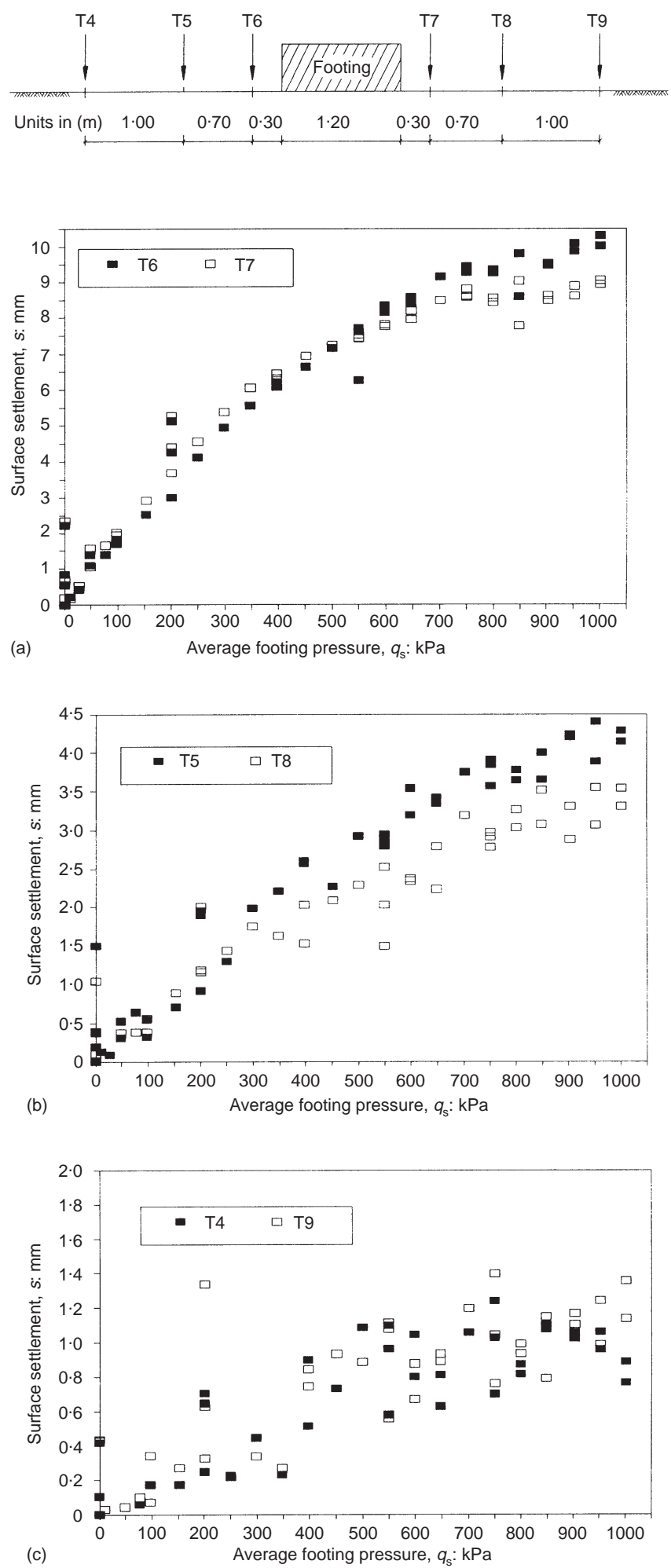

Fig. 5. Settlement of the ground surface around the footing 


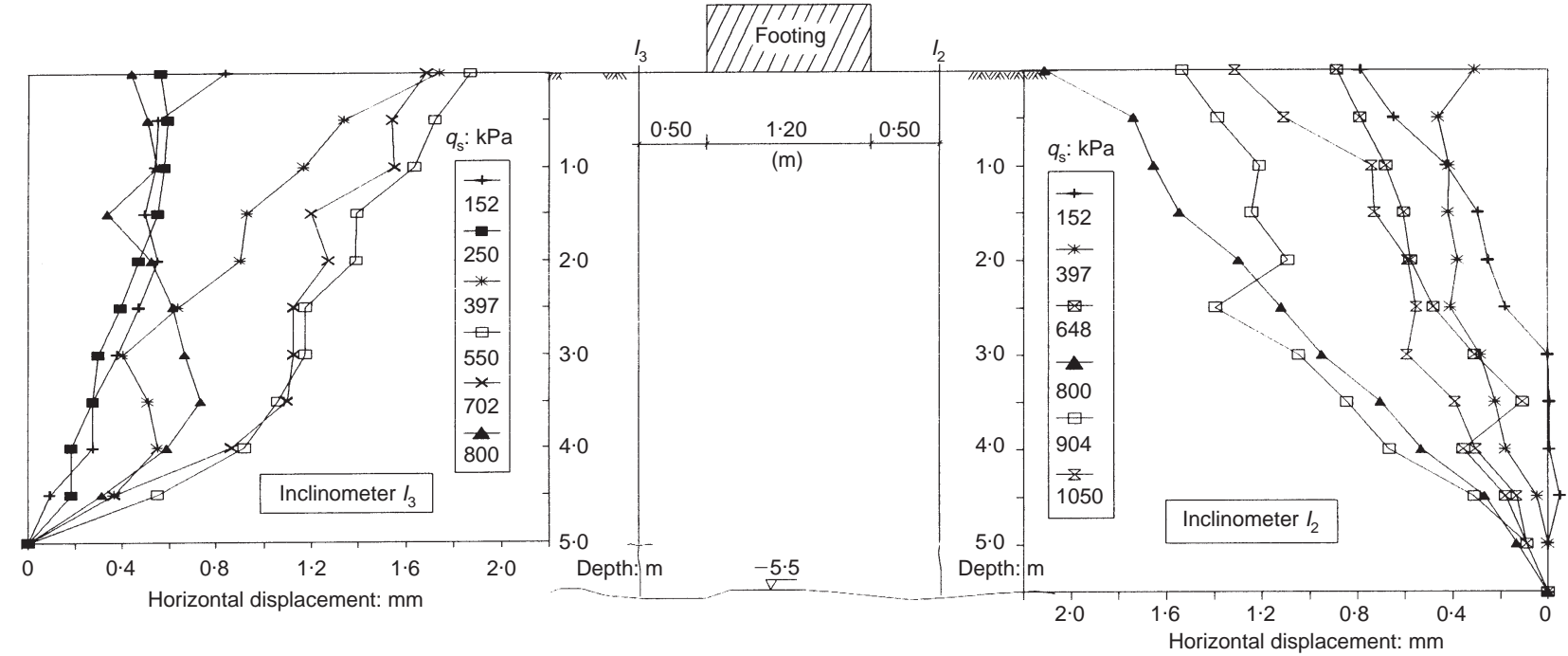

Fig. 6. Horizontal displacement in the ground $0.5 \mathrm{~m}$ away from the footing edge 
some stages of the test. In spite of some scatter, a general movement towards the loaded area can be observed during the initial loading steps followed by a clear reversal of the displacement direction. Nevertheless, final displacements are still directed towards the footing.

\section{Note on the type of failure}

The shape of the pressure-settlement curve is typical of a punching shear failure mode. It should also be noted that the end of the test corresponded to a $100 \mathrm{~mm}$ settlement of the footing base while the ground surface pins situated at $0.3 \mathrm{~m}$ from its border did not reach values of settlement greater than $10 \mathrm{~mm}$ (see Fig. 5(a)). The interpretation of the curve with the purpose of estimating the bearing capacity of the footing is beyond the scope of this paper.

\section{Allowable pressure evaluation}

In order to establish the serviceability limit state pressure the criterion proposed by Décourt (1992) was adopted as a reference. This stipulates that the allowable pressure on a shallow foundation on residual soil should correspond in its effect to a settlement of $6.0 \mathrm{~mm}$ for a $0.8 \mathrm{~m}$ diameter plate load test. This represents a settlement of $0.75 \%$ of the diameter of the loading surface, which gives a settlement of $9 \mathrm{~mm}$ in the present case.

For the footing test curve (Fig. 4) a $9 \mathrm{~mm}$ settlement corresponds to an applied pressure of about $195 \mathrm{kPa}$.

\section{INDUCED STRAINS IN THE GROUND}

Figure 7(a) illustrates the maximum principal (vertical) strain distribution under the centre of the footing obtained from a simplified non-linear elastic analysis, to be presented below, whose results closely fit the first part of the observed pressuresettlement curve. Results are shown for three values of the applied pressure: 100, 200 and $400 \mathrm{kPa}$, corresponding to a value near to the serviceability limit state pressure and to half and twice that value.

Figure 7(b), in which a logarithmic scale is used for the strain, shows clearly that, for pressures of 100 and $200 \mathrm{kPa}$, strain values exceed $10^{-3}$ only in a restricted zone adjacent to the footing.

These results corroborate evidence from other authors (Jardine, Potts, Fourie \& Burland, 1986; Burland, 1989; Tatsuoka \& Shibuya, 1992; Jardine, 1995; Tatsuoka \& Kohata, 1995) of the rather low strain levels involved in a number of soil-structure interaction problems, including shallow foundations, under common working conditions.

A considerable influence of the cemented struc- ture of the soil on the behaviour of the footing is therefore to be expected.

\section{LABORATORY TESTING FOR MECHANICAL CHARACTERIZATION \\ Note on sampling}

Laboratory tests for mechanical characterization were carried out on undisturbed samples taken from large blocks trimmed in open ditches at a depth of $0.5-1 \mathrm{~m}$ below the level of the footing base. All the sampling and handling procedures were undertaken with the utmost care in order to preserve the natural structure of the saprolitic soil.

Taking into account, on the one hand, the homogeneity of the ground underneath the footing to depths of about $6 \mathrm{~m}$ (see Fig. 2 and Table 1) and, on the other hand, the conclusions on induced strains that have just been presented, the abovementioned blocks can be taken as representative of the saprolitic soil most intensely affected by the loading of the footing.

Oedometer and triaxial specimens were obtained by driving the rings or split tube samplers into the blocks with the help of a static trust. The requirements of GCO (1990) about the cutting shoe, the wall friction (smooth inox steel faces) and the use of a non-return valve, have been adopted.

It is recognized that tube sampling may significantly reduce stiffness and strength of soils (Hight, Böese, Butcher, Clayton \& Smith, 1992). Nevertheless, the very fragile structure of this granitic residual soil did not allow the use of trimming methods to obtain specimens directly from the blocks. The use of these methods seems to be more practicable in residual soils with a clayey matrix, such as gneissic soils from Brazil (CostaFilho, Döbereiner, De Campos \& Vargas, 1989).

\section{Oedometer and isotropic consolidation tests}

Figure 8 includes the results of oedometer tests revealing three distinct zones typical of cemented soils (Vaughan, 1988) and corresponding to different states and ranges of the compressibility index: (i) 'stable', $C_{\mathrm{r}}=0.007-0.018$; (ii) 'metastable', $C_{\mathrm{cs}}=0 \cdot 129-0 \cdot 289$; and (iii) 'granular or de-structured', $C_{\mathrm{c}}=0 \cdot 101-0 \cdot 172$. In the first state the soil generally preserves its natural cemented structure, while in the third state this structure is completely destroyed; the intermediate state is associated with progressive de-structuring, resulting from the gradual breakage of interparticle bridges by compression. While the first zone can be likened to an overconsolidated state in transported soils, the second, although apparently similar to a normallyconsolidated state, is really a transition state characterized by higher values of compressibility than the same material would have under remoulded 

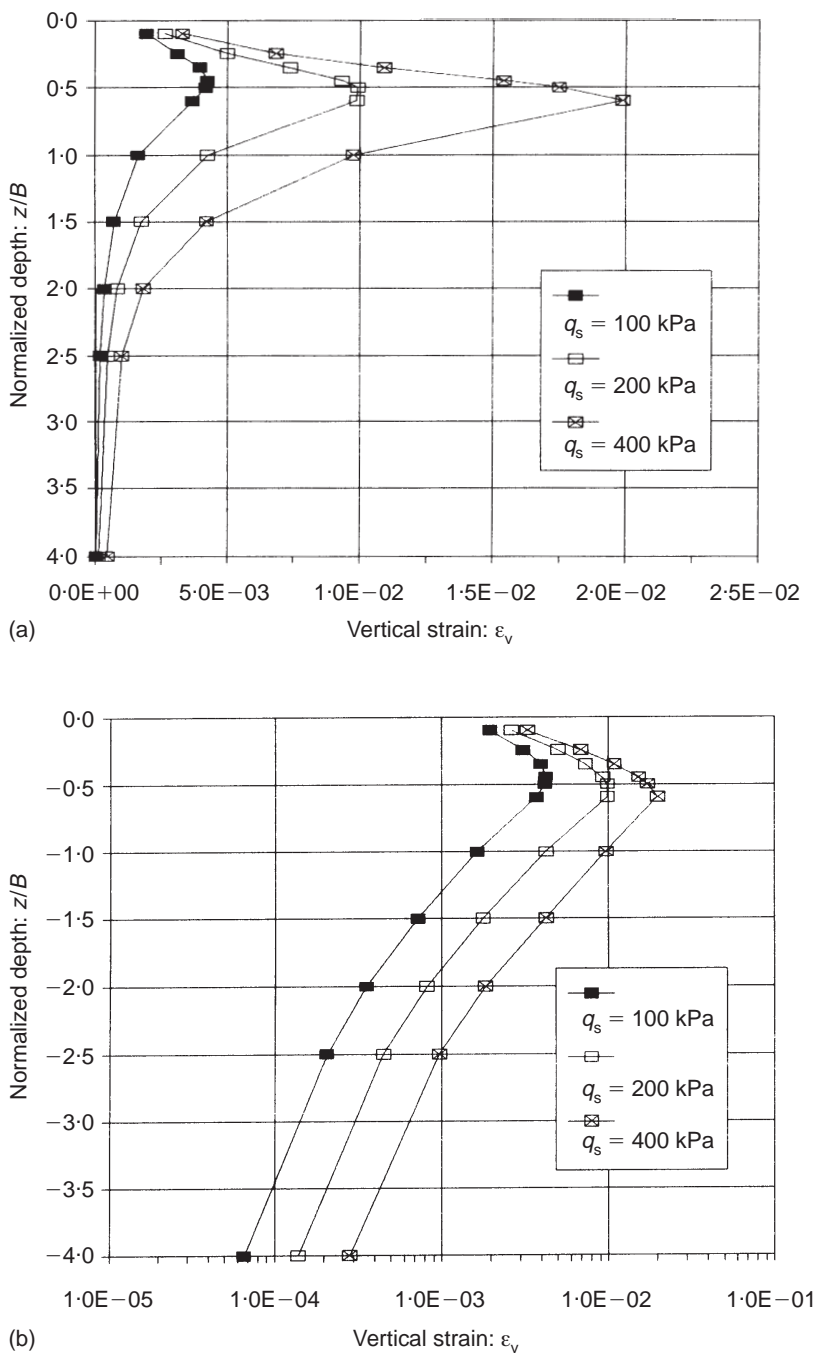

Fig. 7. Maximum principal strain under the centre of the footing from a non-linear elastic simplified analysis: (a) arithmetic scale; (b) logarithmic scale $(z=$ depth; $B=$ footing width)

conditions (granular state). Results for the remoulded soil are also included in the figure for reference.

Therefore, a virtual preconsolidation stress, $\sigma^{\prime}{ }_{\mathrm{vp}}$, can be defined as the value which separates the first two zones, where most of the stress states generated by current loading conditions are situated.

In order to evaluate the virtual preconsolidation stress the method proposed by Pacheco e Silva (1970) was used, since it has demonstrated a good reproducibility in residual soils. The values obtained for virtual preconsolidation stress were $\sigma_{\text {vp }}^{\prime}=85-140 \mathrm{kPa}$ (see Fig. 8), more than 4 times the natural at-rest vertical effective stress.

It is interesting to note that the pressure of $125 \mathrm{kPa}$, which corresponds to a transition of behaviour in the footing load test, falls reasonably within the range found for the virtual preconsolidation stress.

Values of $C_{\mathrm{r}}$ and $C_{\mathrm{c}}$ from the tests are reasonably consistent with those commonly reported in the literature for similar soils (Lacerda, Sandroni, Collins, Dias \& Prusza, 1985). Nevertheless, the values of the tangent-drained constrained modulus calculated for the same consolidation effective 


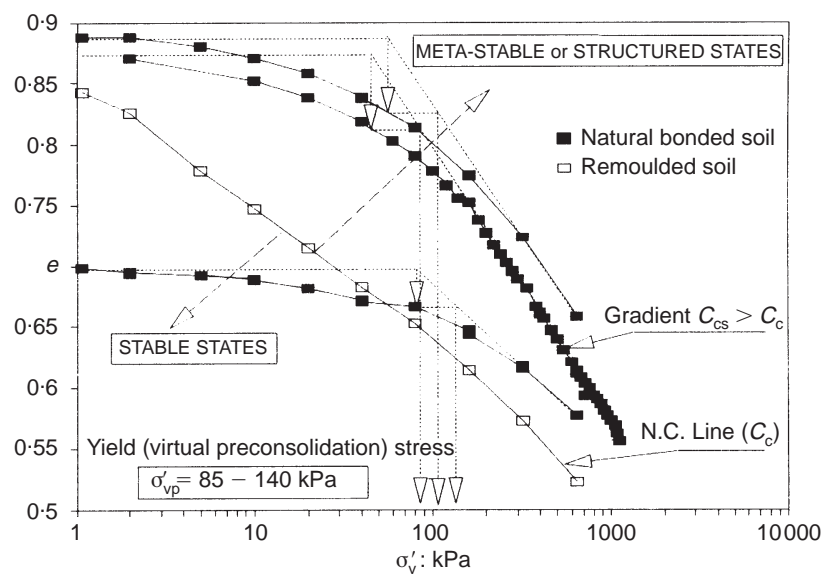

Fig. 8. Oedometer curves - state definition

stresses are substantially lower than the corresponding tangent Young's moduli obtained from triaxial tests (described in the following section) after taking into account the effect of Poisson's ratio. This may be due to the height of these specimens being significantly smaller than that of the triaxial specimens, leading to greater damage during preparation and handling. At small strains, bedding and contact problems may also have contributed to that trend.

Isotropic consolidation tests with local measurement of axial and radial strain provided values of the virtual isotropic preconsolidation stress of $\sigma^{\prime}{ }_{\text {mp }}=40-60 \mathrm{kPa}$. This range is slightly lower than the one deduced from the oedometer tests: considering $K_{0}=0.38$ and taking the values of $\sigma_{\text {vp }}^{\prime}$ indicated above, $\sigma^{\prime}{ }_{\mathrm{mp}}=50-80 \mathrm{kPa}$. This conclusion corroborates the hypothesis of Vaughan (1988) that yield surfaces for volumetric compression are anisotropic and may be centred on the $K_{0}$ stress axis (see Fig. 9).

\section{Triaxial compression tests}

A large number of triaxial tests were performed with different specimen sizes, consolidation stress conditions and stress-paths.

In this paper are presented just the results from compression tests on specimens of $100 \mathrm{~mm}$ diameter with local strain instrumentation. The local strain was measured with a pair of axial strain inclinometers (Ackerley, Hellings \& Jardine, 1987).

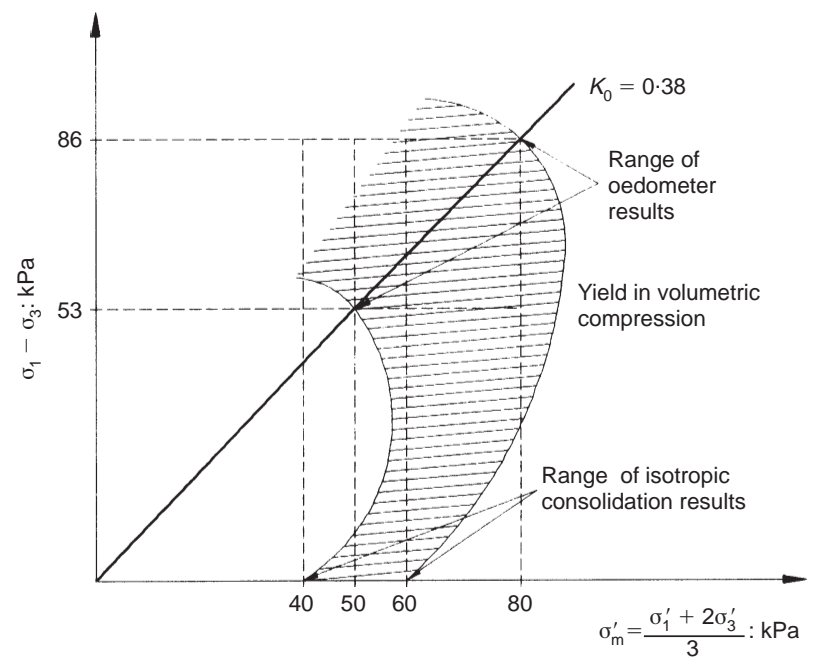

Fig. 9. Yield surfaces for volumetric compression $\left(\sigma_{1}=\right.$ vertical stress, $\sigma_{3}=$ horizontal stress) 
The specimens were previously saturated by applying $10 \mathrm{kPa}$ increments of the back and confining pressures - maintaining an effective isotropic stress of $10 \mathrm{kPa}$, up to values of the order of $300 \mathrm{kPa}$ to achieve full saturation.

The adopted rate of deformation was $0.002 \mathrm{~mm} / \mathrm{min}$, chosen to fulfil the requirements of drained shear conditions. Intermediate unload-reload cycles were performed starting at low to moderate stress levels.

Peak strength parameters obtained from these tests showed a good consistency - ranges of 37$38^{\circ}$ for the angle of shearing resistance and 9$12 \mathrm{kPa}$ for the effective cohesion.

In Fig. 10 stress-strain curves from one of the tests obtained by classical (external LVDT) and local strain measurement systems are compared. For these soils, as for many others, the former technique leads to rather unrealistic values of stiffness. The curve for the local instrumentation results is also included in Fig. 11 together with the curves from other tests with similar measurements but different consolidation stresses, $\sigma^{\prime}{ }_{\mathrm{c}}$.

Figure 11 shows that the soil exhibits substantial brittleness for the lowest effective consolidation stress, while for the others the brittle behaviour tends to vanish, probably due to the development of volumetric (collapsible) plastic strains prior to shearing. Thus, for consolidation stresses much higher than the at-rest stress state, the stress-strain response tends to be typical of de-structured materials. For the lower consolidation stresses (10 and $20 \mathrm{kPa})$ peak values of deviatoric stress are mobilized before the highest value of the dilatancy ratio is reached. This seems to indicate that the mechanical behaviour of the saprolitic soil is controlled by cementation between particles rather than by dilatancy phenomena related to particle interlocking. This latter type of behaviour, typical of dense granular transported soils, is not compatible with the fabric of this soil which exhibits a low to medium density $(e=0 \cdot 60-0 \cdot 85)$ for an essentially sandy soil.

In order to study the dependency of stiffness on the effective consolidation stress, two types of Young's modulus were considered: (i) 'pseudo-elastic', $E_{\mathrm{el}}$, deduced from the initially-linear reload branch of an intermediate unload-reload cycle; (ii) initial tangent, $E_{\mathrm{ti}}$.

Assuming elastic isotropy, the Poisson's ratio $v$ was determined from the same reload branch as $E_{\text {el }}$ (Lade, 1988). The average value obtained was $v_{\mathrm{el}}=0 \cdot 26$. It is interesting that this leads to an elastic coefficient of earth pressure at rest of:

$$
K_{0}=v /(1-v)=0.35
$$

which is reasonably consistent with the in situ SBPT results.

The analysis of the results, expressed on normalized logarithmic scales in Fig. 12, shows that the dependency of these moduli on the consolidation stress is bilinear, with a noticeable change of slope at stresses of the order of $50-60 \mathrm{kPa}$. This shows the favourable contribution to the soil stiffness of the natural cemented structure for the lower consolidation stresses.

It is systematically observed that $E_{\mathrm{el}}$ values are 2 to 3 times greater than the values of $E_{\mathrm{ti}}$. This discrepancy is believed to be due to slight movements of the inclinometer footings anchored on the wall of the specimens which significantly affect the initial sections of the stress-strain curves and,

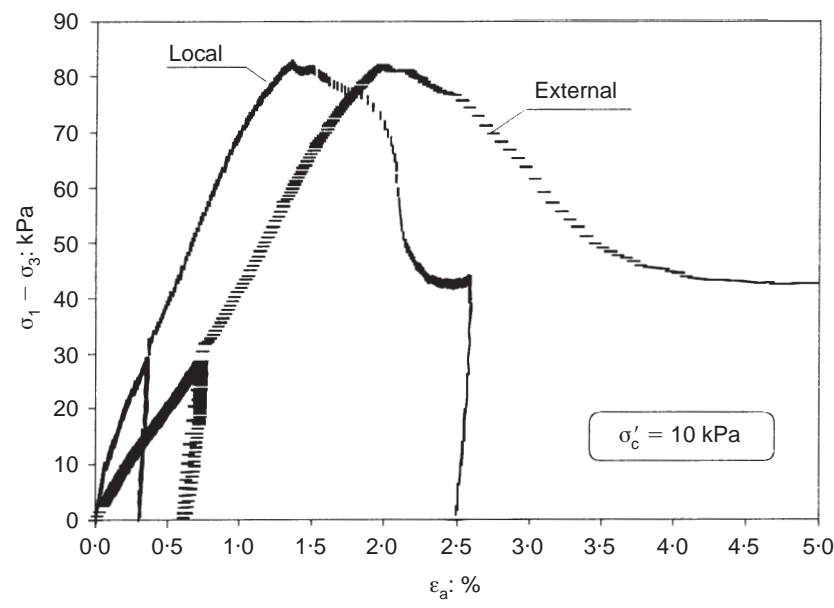

Fig. 10. CID triaxial test $\left(\sigma^{\prime}{ }_{c}=10 \mathrm{kPa}\right)$ : comparison of stressstrain relations with local and external measurement of axial strain 

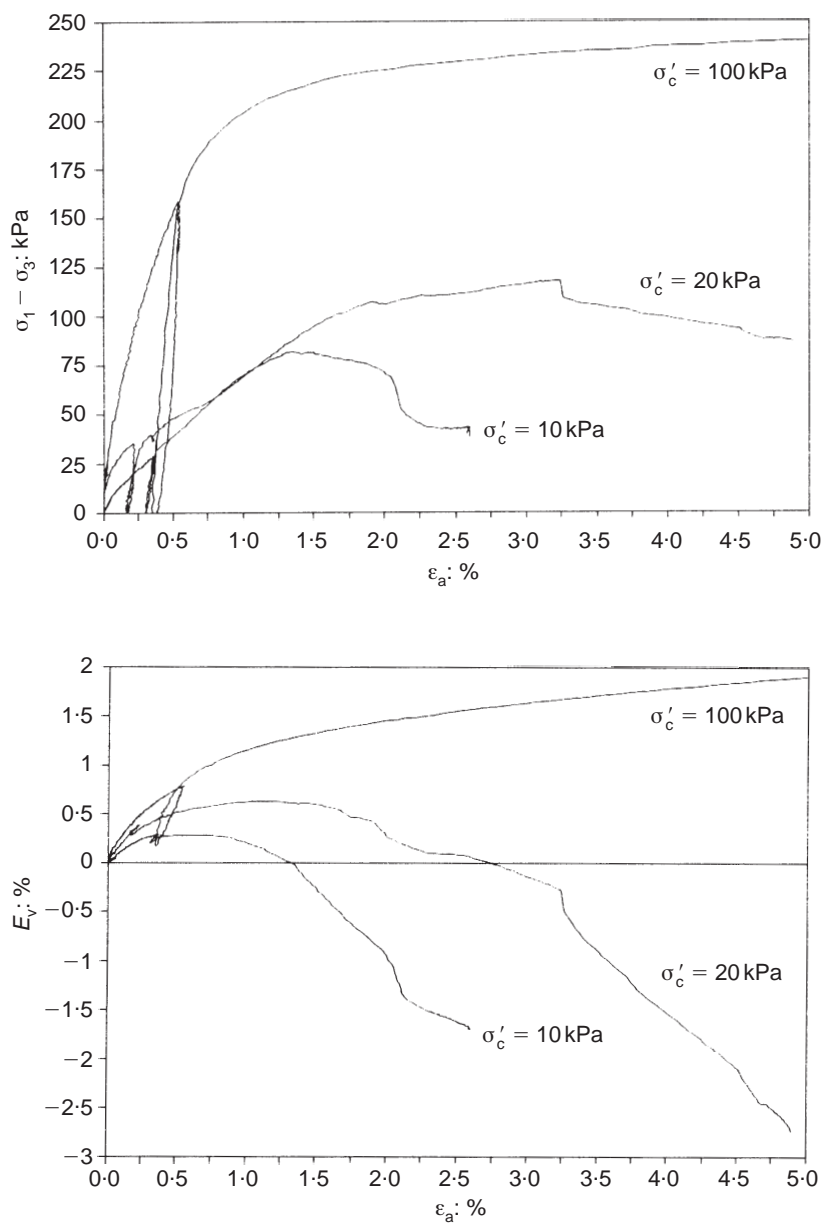

Fig. 11. Results from CID triaxial tests under three distinct consolidation stresses

consequently, the values of $E_{\mathrm{ti}}$.

Several authors (Burland, 1989; Tatsuoka \& Shibuya, 1992; Tatsuoka \& Kohata, 1995) suggest that the small strain shear moduli evaluated from triaxial tests with local strain instrumentation are similar to those obtained by in situ seismic tests. In the present case, for $\sigma_{\mathrm{c}}{ }^{\prime}=10 \mathrm{kPa}$, the shear modulus evaluated from $E_{\mathrm{el}}$ (assuming $v_{\mathrm{el}}=0 \cdot 26$ ), is $G_{\mathrm{el}}=32.8 \mathrm{MPa}$. On the other hand, the maximum shear modulus obtained from cross-hole tests for the same consolidation stress is $G_{0}=102 \mathrm{MPa}$ (see Fig. 2(c)). Therefore, the relation $G_{0} / G_{\text {el }}$ $\cong 3.1$ may represent a largely inevitable effect of sample disturbance.

Tatsuoka \& Shibuya (1992) suggest a correction method for the laboratory stress-strain curves based on the assumption that the dependency of the deformation moduli on the strain level is similar in laboratory and field tests, whilst the absolute values of laboratory moduli may often be lower than those from in situ testing due to sample disturbance, ground non-uniformity and other effects. The method consists of correcting the modulus from laboratory tests by the above-mentioned factor $G_{0} / G_{\mathrm{el}}$.

This procedure has been mostly applied in seismic and other dynamic studies but its use for static problems in which strain levels in the ground are small to moderate does not seem to be unreasonable.

The question of the adequacy of CID triaxial tests for the characterization of the stress-strain behaviour of the saprolitic soil, which exhibits $K_{0}$ much smaller than $1 \cdot 0$, has been analysed by comparing the tangent moduli evaluated for the same deviatoric stress in CID and CAD triaxial tests with the same effective consolidation radial stress $\sigma_{3 \mathrm{c}}^{\prime}$ (see Table 4). 

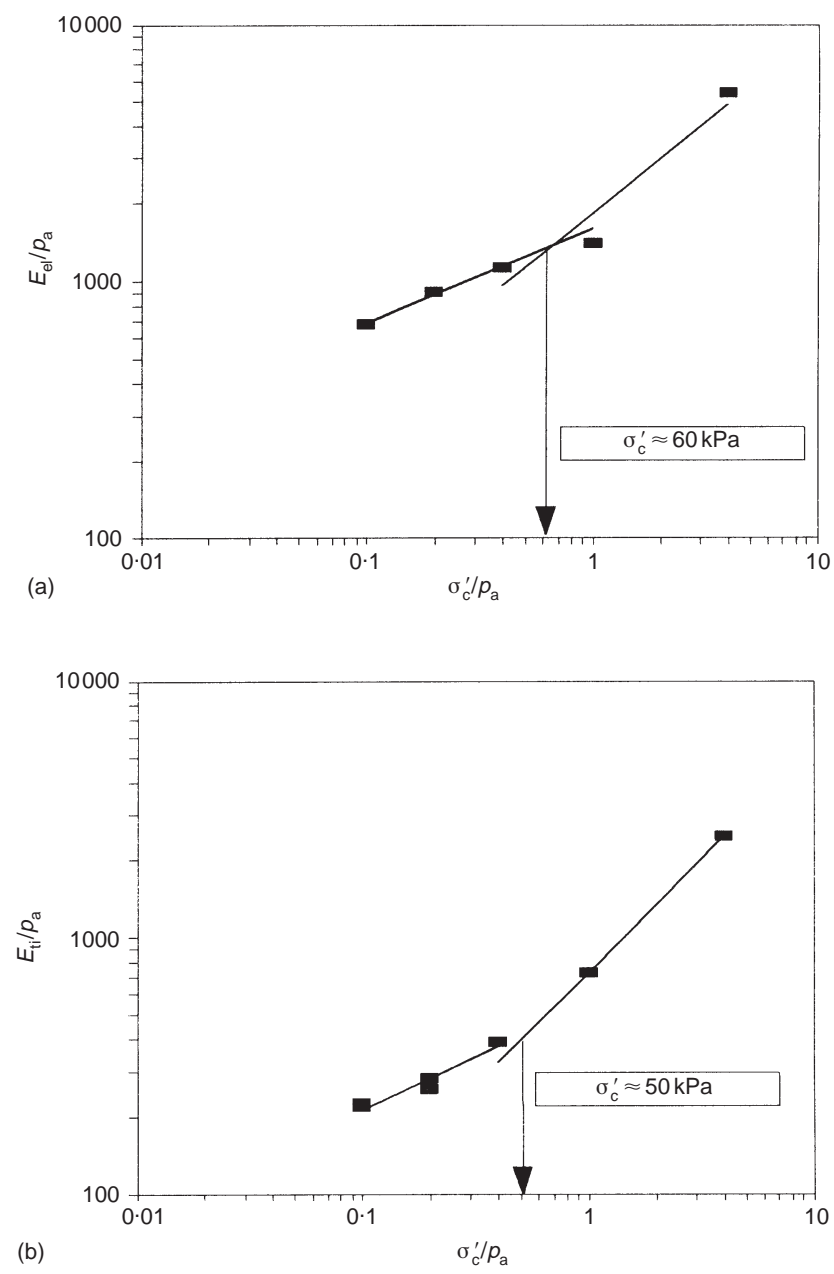

Fig. 12. Young's modulus versus effective consolidation stress, $\sigma_{c}^{\prime}$, from CID triaxial tests: (a) $E_{\mathrm{el}}$; (b) $E_{\mathrm{ti}}$ ( $p_{\mathrm{a}}=$ atmospheric pressure)

Table 4. Tangent Young's modulus from CID and $\operatorname{CAD}\left(K_{0}=0.5\right)$ triaxial tests, with $\sigma^{\prime}{ }_{3 \mathrm{c}}=10 \mathrm{kPa}$

\begin{tabular}{c|r|r}
\hline \multirow{2}{*}{$\begin{array}{c}\sigma_{1}-\sigma_{3}: \\
\mathrm{kPa}\end{array}$} & \multicolumn{2}{|c}{$E_{\mathrm{t}}: \mathrm{MPa}$} \\
\cline { 2 - 3 } & $\mathrm{CID}$ & $\mathrm{CAD}$ \\
\hline 10 & $9 \cdot 60$ & $10 \cdot 42$ \\
$16 \cdot 3$ & 8.38 & 7.96 \\
30 & 7.93 & 7.57 \\
50 & 6.68 & 6.59 \\
\hline
\end{tabular}

The results of these tests, which have all been undertaken with a very low rate of deformation $(0.002 \mathrm{~mm} / \mathrm{min})$, seem to indicate a fair reproducibility in CID tests of stiffness under initial conditions defined by $K_{0}<1$. Thus, if triaxial specimens of this residual soil are isotropically consolidated inside the volumetric yield surface and if local strain measurement is used, CID tests can serve for stiffness evaluation, thereby avoiding the frequent difficulty of fixing an appropriate value of $K_{0}$ to be adopted in a triaxial testing programme.

\section{FOOTING SETTLEMENT EVALUATION BY TRIAXIAL TESTS RESULTS Linear analysis}

Table 5 includes the Young's modulus of the soil for different load stages obtained by back-analysis of the footing load test. The back-analysis assumed a linear elastic layer with constant modulus underlain by a rigid base at $6.0 \mathrm{~m}$ depth loaded at the surface by a rigid footing. It should be remembered that the intermediate pressure shown in the table approximately corresponds to the allowable pres- 
Table 5. Secant Young's modulus, $E_{\mathrm{s}}$, evaluated from the footing load test

\begin{tabular}{llcc}
\hline$q_{\mathrm{s}}: \mathrm{kPa}$ & 95 & $190\left(^{*}\right)$ & 380 \\
\hline$E_{\mathrm{s}}: \mathrm{MPa}$ & $23 \cdot 1$ & $19 \cdot 4$ & $15 \cdot 3$
\end{tabular}

(*) Approximately corresponding to the allowable pressure for serviceability limit state design.

sure according to the criterion of Décourt (1992) for residual soils.

Assuming elastic conditions, it is possible to evaluate the position of the so-called settlement centre, $z_{1}$ (Carrier \& Christian, 1973). For circular foundations, its position depends on the variation of the Young's modulus with depth and on the diameter of the footing, $B$. For the present case it is expected that $z_{1} \cong B$.

Considering the results of the CID triaxial tests under a consolidation effective stress corresponding to a depth similar to the footing diameter, the tangent Young's modulus for the $K_{0}$ shear stress level was found to be $E_{\mathrm{tK} 0}=7.8 \mathrm{MPa}$.

The use of such a modulus in an elastic analysis of the footing load test would lead to a crude overestimation of the observed settlement.

However, if $E_{\mathrm{tK} 0}$ is multiplied by the abovementioned factor $G_{0} / G_{\text {el }}$ one obtains $24 \cdot 3 \mathrm{MPa}$. This value would provide a good prediction of the settlement for typical working conditions (applied pressure up to about $200 \mathrm{kPa}$, see Table 5).

This observation suggests that the application of a design methodology which corrects the values of the deformation modulus from triaxial tests by factors referenced to field tests (cross-hole tests or similar) may give good results. This is further explored in the following section.

\section{Simplified non-linear elastic analysis}

Taking into account the methodology proposed by Wahls \& Gupta (1994), the dependency of the Young's modulus on depth and on the shear stress level in the soil can be evaluated through the results of triaxial tests using the classical equation:

$$
E_{\mathrm{tl}}=p_{\mathrm{a}} K_{\mathrm{l}}\left(\sigma_{\mathrm{ml}}^{\prime} / p_{\mathrm{a}}\right)^{\mathrm{nl}}
$$

where $p_{\mathrm{a}}$ is the atmospheric pressure and $K_{1}$ and $n_{1}$ are dimensionless parameters.

Using the results of several triaxial tests with different consolidation stresses and evaluating, for each test, the tangent modulus, $E_{\mathrm{tl}}$, for distinct shear stress levels, it is possible to compute, for each of these levels, the corresponding values of $K_{1}$ and $n_{1}$. This is reported in Table 6 where $q$ and $q_{\mathrm{f}}$ are the current deviatoric stress and the deviatoric stress at failure, respectively.

A law for the dependency of $K_{1}$ and $n_{1}$ on the shear stress level has then to be defined. Since $n_{1}$ exhibits a modest variation, a constant average value is adopted, $n_{1}=0 \cdot 375$. For expressing the dependency of $K_{1}$ on the stress level, $q / q_{\mathrm{f}}$ (computed from the results of corresponding triaxial tests), the following function is assumed:

$$
K_{1}=C_{\mathrm{K}} \log \left(q / q_{\mathrm{f}}\right)_{1}
$$

the evaluation of $C_{\mathrm{K}}$ being outlined on Fig. 13.

Table 6. Values of $K_{1}$ and $n_{1}$ as function of the stress level

\begin{tabular}{c|c|c|c|c|c}
\hline$q / q_{\mathrm{f}}: \%$ & 0 & 10 & 25 & 50 & 75 \\
\hline$K_{1}$ & 520 & 256 & 142 & 88 & 74 \\
$n_{1}$ & $0 \cdot 383$ & $0 \cdot 450$ & $0 \cdot 488$ & $0 \cdot 234$ & $0 \cdot 328$ \\
\hline
\end{tabular}

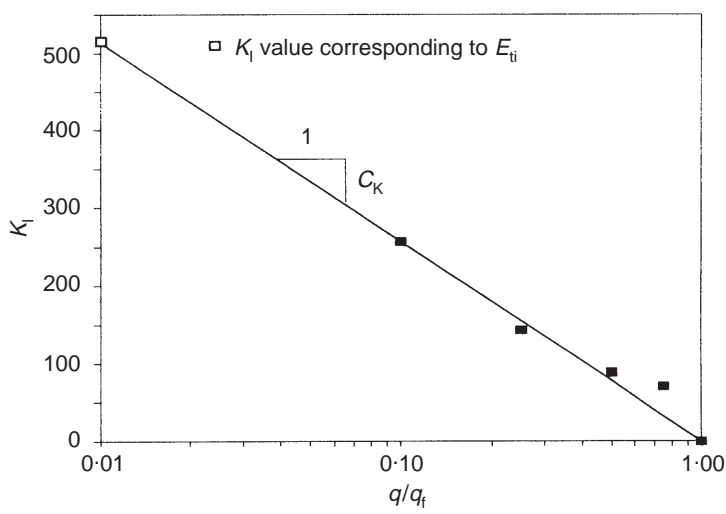

Fig. 13. Variation of $K_{1}$ with the stress level 
These parameters are subsequently used in a simplified non-linear elastic analysis of the footing load test.

The analysis requires the discretization of the ground in several layers $(j=1, m)$ with a thickness of $\Delta h_{\mathrm{j}}$ and the application of a stepped $(i=1, n)$ loading process. For the applied loading step, $\Delta q_{\mathrm{si}}$, the vertical and mean effective stress increments in each layer $j, \Delta \sigma_{\mathrm{vij}}$ and $\Delta \sigma_{\mathrm{mij}}$, are calculated by using, for instance, the $I_{\mathrm{vj}}$ and $I_{\mathrm{mj}}$ factors proposed by Giroud (1972) for rigid circular foundations:

$$
\begin{aligned}
\Delta \sigma_{\mathrm{vij}} & =I_{\mathrm{vj}} \Delta q_{\mathrm{si}} \\
\Delta \sigma_{\mathrm{mij}} & =(1+v) I_{\mathrm{mj}} \Delta q_{\mathrm{si}}
\end{aligned}
$$

Stresses at each stage are defined by:

$$
\begin{aligned}
& \sigma^{\prime}{ }_{\mathrm{vij}}=\sigma^{\prime}{ }_{\mathrm{v}(\mathrm{i}-1) \mathrm{j}}+\Delta \sigma_{\mathrm{vij}}=\sigma^{\prime}{ }_{\mathrm{v} 0 \mathrm{j}}+\Sigma_{\mathrm{i}} \Delta \sigma_{\mathrm{vij}} \\
& \sigma^{\prime}{ }_{\mathrm{mij}}=\sigma^{\prime}{ }_{\mathrm{m}(\mathrm{i}-1) \mathrm{j}}+\Delta \sigma_{\mathrm{mij}}=\sigma^{\prime}{ }_{\mathrm{m} 0 \mathrm{j}}+\Sigma_{\mathrm{i}} \Delta \sigma_{\mathrm{mij}}
\end{aligned}
$$

where

$$
\sigma^{\prime}{ } 0 \mathrm{j}=\sigma^{\prime}{ }_{\mathrm{v} 0 \mathrm{j}}\left(1+2 \mathrm{~K}_{0}\right) / 3
$$

The corresponding vertical strain increments are calculated by:

$$
\Delta \varepsilon_{\mathrm{vij}}=I_{\mathrm{ej}} \Delta q_{\mathrm{si}} / E_{\mathrm{tij}}
$$

in which

$$
I_{\mathrm{ej}}=(1+v)\left[I_{\mathrm{vj}}-3 v I_{\mathrm{mj}}\right]
$$

and $E_{\mathrm{tij}}$ represents the tangent Young's modulus. The settlement increment, $\Delta s_{\mathrm{i}}$, for each load step can be defined by the equation:

$$
\Delta s_{\mathrm{i}}=\Delta q_{\mathrm{si}} \Sigma_{\mathrm{j}}\left[I_{\mathrm{ej}} \Delta h_{\mathrm{j}} / E_{\mathrm{tij}}\right]
$$

and the total settlement is given by:

$$
s_{\mathrm{i}}=\Sigma_{\mathrm{i}} \Delta s_{\mathrm{i}}
$$

By means of this incremental process it is possible to select, for each layer, the appropriate deformation modulus. A value of $E_{\mathrm{tij}}$ is adopted, for each increment, by considering the average of the values of $\sigma^{\prime}{ }_{\mathrm{m}}$ and $q / q_{\mathrm{f}}$ corresponding to the current step $(i)$ and to the previous one $(i-1)$. The value of $q_{\mathrm{f}}$ is calculated assuming a MohrCoulomb law with the $\phi^{\prime}$ and $c^{\prime}$ parameters deduced from triaxial tests and the value of $q$ given by:

$$
q_{\mathrm{ij}}=\sigma^{\prime}{ }_{\mathrm{vij}}-\sigma^{\prime}{ }_{\mathrm{hij}}=1 \cdot 5\left(\sigma^{\prime}{ }_{\mathrm{vij}}-\sigma^{\prime}{ }_{\mathrm{mij}}\right)
$$

The curve obtained by the application of this methodology to the footing load test is compared in Fig. 14(a) with the experimental one. The analytical result is rather poor, as could be easily predicted taking into account the linear back-analysis presented above.
Although the linear elastic assumption for the calculation of the incremental stresses may affect the analytical results (Jardine et al., 1986), it is believed that the main reason for discrepancy is the under-estimation of stiffness by triaxial testing.

Figure 14(b) illustrates a comparison between the observed settlements and the results of the application of the non-linear simplified procedure in which the deformation modulus is now corrected by the factor $G_{0} / G_{\mathrm{el}}$. The linear diagram obtained by the application of the linear elastic analysis with a constant modulus equal to $E_{\mathrm{tK} 0} . G_{0} / G_{\mathrm{el}}$ is also shown.

The agreement between the observed results and the analytical curve obtained on the basis of the corrected modulus is very good up to a value twice the allowable pressure. Even the linear elastic analysis gives a good agreement up to loads close to the allowable pressure.

\section{FOOTING SETTLEMENT EVALUATION USING SPT AND CPT TESTING RESULTS \\ SPT tests}

Some empirical methods for the evaluation of settlements of shallow foundations are based on sensitivity analyses of the influencing factors: the applied pressure, $q_{\mathrm{s}}$, the footing width or diameter, $B$, and the results from in situ tests like $N_{\mathrm{SPT}}$ or $q_{\mathrm{c}-\mathrm{CPT}}$.

The expression of Burland \& Burbidge (1985), based on over 200 records of settlement of foundations on sands and gravels, is well known:

$$
s=\alpha_{\mathrm{BB}} q_{\mathrm{s}} \mathrm{B}^{0 \cdot 7} / \mathrm{N}_{\mathrm{SPT}}{ }^{1 \cdot 4}
$$

with $\alpha_{\mathrm{BB}}$ varying between 0.93 and 3.09 , the average being 1.71 .

The application of this equation to the footing load test provides a settlement two to three times the observed one for working conditions. Rocha Filho (1986) reported ratios of 1.5 to 2.5 after the application of the same equation to Brazilian saprolitic soils.

\section{CPT tests}

The semi-empirical method of Schmertmann (1970) assumes a simplified distribution of the influence factor for the vertical strains under the footing, whose values are computed on the basis of a deformation modulus variable with depth in proportion to the CPT cone resistance:

$$
E_{\mathrm{si}}=\alpha q_{\mathrm{ci}}
$$

Schmertmann, Hartman \& Brown (1978) found $\alpha=2.5$ for axisymetric conditions in granular soils.

It should be remarked that, in spite of using a constant modulus for a given depth, Schmertmann's 

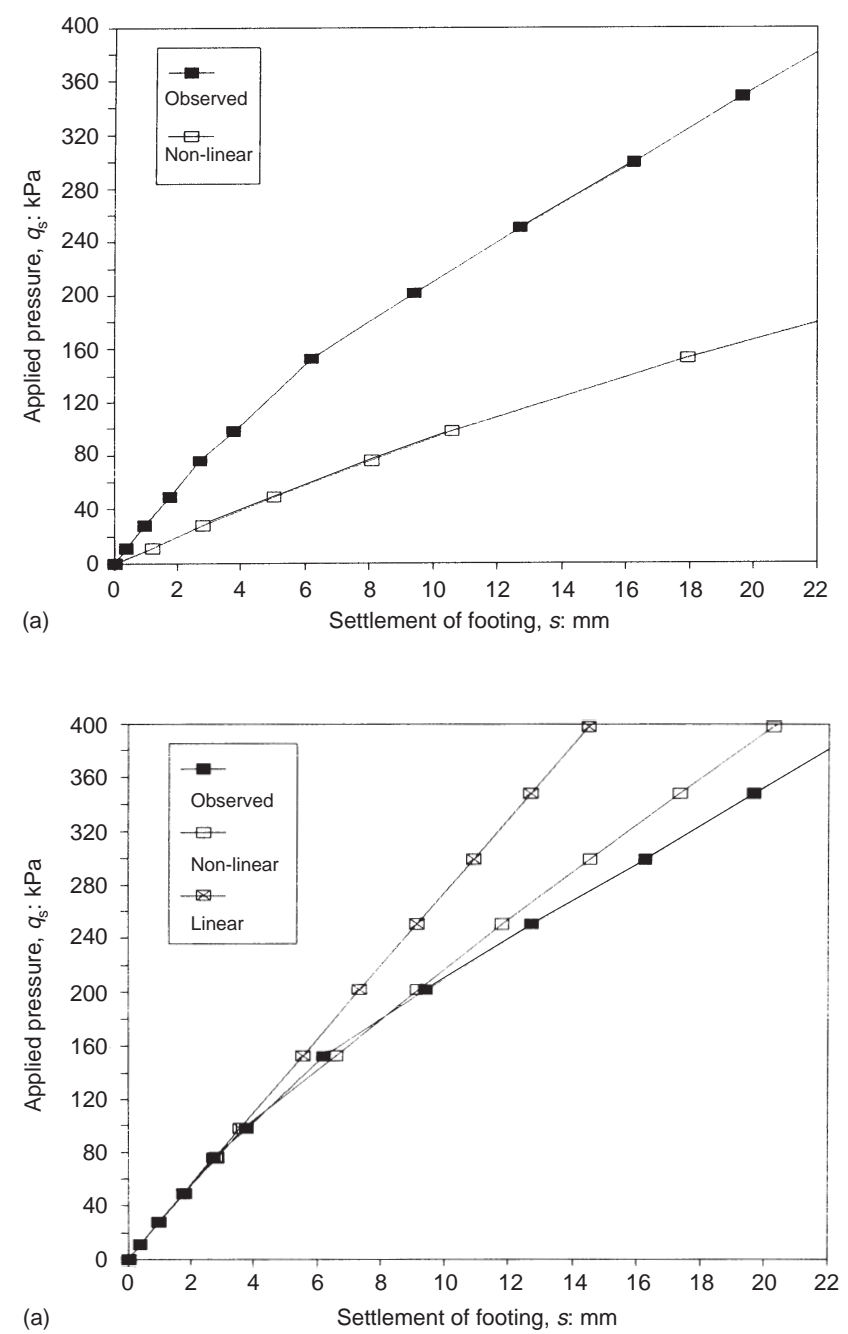

Fig. 14. Footing load test: comparison of the experimental curve with the one calculated by simplified non-linear analysis: (a) deformation modulus from triaxial tests; (b) deformation modulus corrected by the factor $G_{0} / G_{\text {el }}$

method provides a non-linear pressure-settlement curve, since the strains depend on the ratio between the incremental pressure and the initial effective vertical stress at foundation level.

This method was applied to the footing load test by adjusting the $\alpha$ parameter in order to fit the observed curve. As shown in Fig. 15, the best agreement was achieved for $\alpha$ values of 4.0 to $4 \cdot 5$. These relatively high values should probably be attributed to the influence of the cemented structure of the saprolitic soil, being situated in the range referred to by Robertson \& Campanella (1988) as applicable for aged sands.

\section{CONCLUSIONS}

The paper has summarized the work conducted at an experimental site to investigate the behaviour of a saprolitic soil from granite.

The general characterization of the residual soil has been presented in terms of the results of SPT, $\mathrm{CPT}$ and $\mathrm{CH}$ in situ tests, as well as the grain size distribution, Atterberg limits, physical properties and weathering indices. A carefully-controlled loading test of a circular reinforced concrete footing has been described and the results have been analysed with an emphasis on the pressure-settlement curve for pressures up to the serviceability limit. 


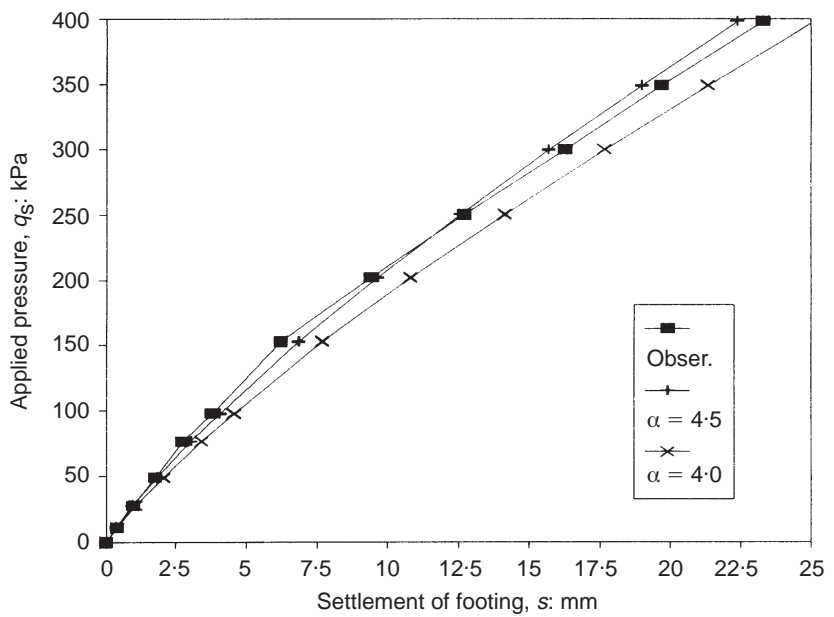

Fig. 15. Back-analysis of the footing load test using CPT results and the semi-empirical method of Schmertmann (1970)

The results presented of oedometer, isotropic compression and triaxial compression tests on high quality block samples using local strain instrumentation can be considered as typical of soils with a cemented structure. In spite of the evidence of such a structure in the laboratory test results and of the careful choice of the parameters expressing the stiffness of the soil (depending on the mean effective stress and on the shear stress level), a simplified non-linear elastic analysis based on these parameters provides a considerable overestimation of the observed settlements.

This discrepancy suggests that, notwithstanding the care taken in the sampling and testing of the soil, the structure of the specimens may have been substantially affected. A substantial part of this damage may have been induced by tube sampling from the blocks.

The evidence of that structural damage is the high value (about 3 ) reached by the ratio $G_{0} / G_{\text {el }}$ (maximum shear modulus from cross-hole tests and from the reload linear branches of triaxial tests, respectively).

The correction of the stiffness parameters by means of the factor $G_{0} / G_{\text {el }}$ resulted in a very good agreement between calculated and observed results. This methodology, combining results from laboratory and in situ tests in a simple and apparently favourable way, is an approach which has been already explored by other authors.

The interpretation of the footing load test by means of the Burland \& Burbidge (1985) equation based on SPT results leads to an overestimation of the observed settlement by a factor of $2-3$. If the semi-empirical method of Schmertmann (1970) is applied together with the CPT results the footing settlement is accurately reproduced provided that the value of $\alpha=E / q_{\mathrm{c}}$ is taken in the range of $4 \cdot 0$ to $4 \cdot 5$. Both methods identify this saprolitic soil in the global typology of cemented or granular aged soils.

\section{ACKNOWLEDGEMENTS}

The authors are indebted to Dr José Marques and to Dr John Greenfield for their kind suggestions concerning the presentation of the paper.

\section{REFERENCES}

Ackerley, S. K., Hellings, J. E. \& Jardine, R. J. (1987). Discussion on 'A new device for measuring local axial strains on triaxial specimens' by C. R. Clayton and S. A. Khatrush, 1987, Géotechnique 37, No. 3, 413-417.

ASTM D1194 (1989). Bearing Capacity of Soil for Static Load and Spread Footings. Annual Book of ASTM Standards 04.08, 192-194.

ASTM D2487 (1989). Classification of Soils for Engineering Purposes. Annual Book of ASTM Standards 04.08, 288-297.

Burland, J. B. (1989). Ninth Laurits Bjerrum Memorial Lecture: 'Small is beautiful'. The stiffness of soils at small strains. Canadian Geotechnical Journal 26, 499-516.

Burland, J. B. \& Burbidge, M. C. (1985). Settlement of foundations on sand and gravel. Proc. Institution of Civil Engineers 78, 1325-1381.

Carrier III, W. D. \& Christian, J. T. (1973). Rigid circular plate resting on a non-homogeneous elastic halfspace. Géotechnique 23, No. 1, 67-84.

Collins, R. (1985). Towards characterisation of tropical soil microstructure. Proc. 1st Int. Conf. on Geome- 
chanics in Tropical Lateritic and Saprolitic Soils, Brasilia 1, 85-96, and Discussion, 3, 207-209.

Costa-Filho, L. M., Döbereiner, L., De Campos, T. M. P. \& Vargas Jr, E. (1989). Fabric and engineering properties of saprolites and laterites. General report/Discussion Session 6 - Invited lecture. Proc. 12th ICSMFE, Rio de Janeiro 4, 2463-2476.

da Fonseca, A. V. (1996). Geomechanics in Residual Soils from Porto Granite. Criteria for the Design of Shallow Foundations (in Portuguese). PhD Thesis, University of Porto.

da Fonseca, A. V., Matos Fernandes, M., Cardoso, A. S. \& Martins, J. B. (1994). Portuguese experience on geotechnical characterisation of residual soils from granite. Proc. 13th Int. Conf. Soil Mec., New Delhi 1, $377-380$.

Décourt, L. (1992). SPT in non classical material. Proc. US/Brazil Geotechnical Workshop on Applicability of Classical Soil Mechanics Principles in Structured Soil Belo Horizonte, 67-100.

GCO (1990). Guide to Site Investigation. Reprint. Geotechnical Engineering Office, Hong Kong.

Giroud, J. P. (1972). Tables pour le calcul des fondations. Dunod.

GOST 20276 (1985). Soils. Field Methods for Determining Deformation Characteristics. National Soviet standard, translated from Russian into English in LNEC Technical Information Report ICT - ITG19.

Hight, D. W., Böese, R., Butcher, A. P., Clayton, C. R. I. \& Smith, P. R. (1992). Disturbance of the Bothkennar clay prior to testing. Géotechnique 42, No. 2, 199217.

Jardine, R. J. (1995). One perspective of the pre-failure deformation characteristics of some geomaterials. Proc. 1st Int. Conf. on Pre-failure Deformation Characteristics of Geomaterials, Sapporo 2, 855885.

Jardine, R. J., Potts, D. M., Fourie, A. B. \& Burland, J. B. (1986). Studies of the influence of non-linear stressstrain characteristics in soil-structure interaction. Géotechnique 36, No. 3, 377-396.

Lacerda, W. A., Sandroni, S. S., Collins, K., Dias, R. D. \& Prusza, V. Z. (1985). Compressibility properties of lateritic and saprolitic soils. Progress Report (19821985), Com. on Tropical Soils of the ISSMFE. ABMS, Brasília, 85-113.

Lade, P. V. (1988). Model and parameters for the elastic behaviour of soils. Proc. 6th Int. Conf. Numerical Methods in Geomechanics, Innsbruck 1, 359-364.
Lumb, P. (1962). The properties of decomposed granite. Géotechnique 12, No. 3, 226-243.

Pacheco e Silva, F. (1970). A new construction for graphic evaluation of preconsolidation stress of a soil sample (in Portuguese). Proc. IV COBRA MSFE, Rio de Janeiro 1, 225-232.

Robertson, P. K. (1990). Soil classification using the cone penetration test. Canadian Geotechnical Journal 27, $151-158$

Robertson, P. K. \& Campanella, R. G. (1988). Guidelines for geotechnical design using CPT and CPTU data. Report of Federal Highway Administration, Washington, FAWA-PA-87-014-84-24, II.

Rocha Filho, P. (1986). Discussion on 'Settlement of foundations on sand and gravel' by J. B. Burland \& M. C. Burbidge, 1985. Proc. of Institution of Civil Engineers 79, 1633-1635.

Rocha Filho, P., Antunes, F. S. \& Falcão, M. F. G. (1985). Qualitative influence of the weathering degree upon the mechanical properties of a young gneissic residual soil. Proc. 1st Int. Conf. on Geomechanics in Tropical Lateritic and Saprolitic Soils, Brasilia 1, 281-294.

Schmertmann, J. H. (1970). Static cone to compute static settlement over sand. J. Soil Mech. Fdn Div. Am. Soc. Civ. Engrs 96, No. 3, 1011-1043.

Schmertmann, J. H., Hartman, J. P. \& Brown, P. R. (1978). Improved strain influence factor diagram. $J$. Geot. Eng. Div. Am. Soc. Civ. Engrs 104, No. 8, 1131-1135.

Tatsuoka, F. \& Shibuya, S. (1992). Deformation characteristics of soils and rocks from field and laboratory tests. Proc. 9th Asian Regional Conf. Soil Mec., Bangkok 2, 101-170.

Tatsuoka, F. \& Kohata, Y. (1995). Stiffness of hard soils and soft rocks in engineering applications. Proc. 1st Int. Conf. on Pre-failure Deformation Characteristics of Geomaterials, Sapporo 2, 947-1063.

Vaughan, P. R. (1988). Characterising the mechanical properties of in situ residual soils. Proc. 2nd Int. Conf. on Geomechanics in Tropical Soil, Singapore 2, 469-486.

Vaughan, P. R. \& Kwan, C. W. (1984). Weathering, structure and in situ stress in residual soils. Géotechnique 34, No. 1, 43-59.

Wahls, H. E. \& Gupta, M. (1994). Settlement of shallow foundations on sand. Vertical and Horizontal Deformations of Foundations and Embankments, ASCE Geot. Spec. Pub. 40, Vol. 1, 190-260. 